\title{
Alder bør ikke styre behandlingen av eldre kreftpasienter
}

\author{
Levealderen øker, og høy alder utgjør en risiko for å få kreft. \\ For å avgjøre om eldre pasienter tåler kreftbehandling, kan man \\ ikke bare se på alder.
}

Ved en undersøkelse av 182 pasienter i alderen 70-94 år som ble operert for kreft i tykktarm eller endetarm i Oslo og Akershus, viste det seg at andelen som fikk komplikasjoner etter inngrepet, ikke økte med økende alder. En gruppe pasienter som ved en geriatrisk avdeling ble vurdert som skrøpelige før operasjonen, fikk - ikke overraskende - betydelig flere komplikasjoner enn de øvrige pasientene. Under $2 \%$ av pasientene døde i forbindelse med inngrepet. Dette skriver Siri Rostoft Kristjansson i sin avhandling.

- Aldringsprosessen styres ikke av kalenderen, men av biologien. For å vurdere om en pasient tåler kreftbehandling, må man derfor se på andre forhold enn alder alene. Det kan være forhold som andre sykdommer, funksjonsnivå i dagliglivet, om pasienten lever et aktivt liv, ernæring, depresjon og kognitiv funksjon. Basert på en systematisk oversikt over dette kan man identifisere pasienter som har få funksjonelle reserver, og dermed økt risiko for komplikasjoner. Metoden er hentet fra geriatrien, der man i flere år har vurdert eldre pasienter på denne måten, sier Kristjansson.

Andelen personer over 65 år vil bli større $\mathrm{i}$ årene som kommer. Høyere alder er en av de viktigste risikofaktorene for å få kreft, og antall mennesker som får kreft, vil derfor øke. Dessverre har vi begrenset kunnskap om hvordan eldre med kreft skal behandles, i hovedsak fordi eldre og pasienter med mye komorbiditet eller redusert funksjonsnivå sjelden inkluderes i kliniske studier. Dette er $\mathrm{i}$ ferd med å endre seg fordi stadig flere forskere fatter interesse for fagområdet eldre og kreft.

\section{Tone Bergset}

tone.bergset@legeforeningen.no

Tidsskriftet

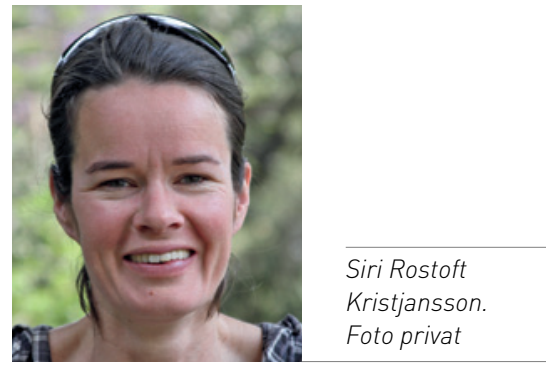

\section{Disputas}

Siri Rostoft Kristjansson disputerte for ph.d.graden ved Universitetet i Oslo 27.10. 2011 med avhandlingen The role of geriatric assessment and frailty measurements in predicting surgical risk and survival in elderly patients with colorectal cancer-a prospective observational cohort study.

\section{Nye prognostiske \\ markører for prostatakreft}

\section{Markører for karvekst og celleadhesjon kan være nyttige prediktorer for tilbakefall og prognose ved prostatakreft.}

Prostatakreft er den nest vanligste kreftformen blant menn i vestlige land. I de fleste tilfeller oppdages sykdommen tidlig, pga. målinger av prostataspesifikt antigen (PSA) i blod, og da er prognosen oftest god. I mange tilfeller overbehandles prostatakreft med kirurgi og stråling, noe som kan føre til unødvendig nedsatt livskvalitet hos mange pasienter. Det er behov for nye markører som kan forutsi klinisk utfall og prognose. Karsten Gravdals studier gir ny kunnskap om markører som er assosiert med kardanning i kreftsvulster.

- Kreftsvulster er avhengige av nydannede blodkar for å vokse. Vi har introdusert en ny metode for å måle dette - basert på nestin, som er en markør for umodne blodkar, og $\mathrm{Ki}-67$, som er en markør for prolifererende celler. Uttrykk av nestin og Ki-67 var 4-5 ganger høyere i avansert prostatakreft enn i lokalisert kreft. I lokalisert kreft hadde uttrykk av nestin og Ki-67 signifikant betydning for tidsrom før biokjemisk residiv, tilbakefall og spredning til skjelettet, sier Gravdal.

- Internasjonalt forskes det på å finne effektiv behandling rettet mot karvekst. Målet er at slik behandling skal bremse vekst av svulster, spredning av sykdommen og vekst av dattersvulster. På sikt kan den nye metoden være nyttig for å kartlegge pasienter som er egnet for terapi rettet mot karvekst, sier han.

For å invadere og spre seg i kroppen må kreftceller endre på overflatemolekyler. Gravdals avhandling viser at nivåer av overflatemolekylene E-cadherin og N-cadherin har betydning for prognosen: Lave nivåer av E-cadherin kombinert med positiv N-cadherin var en uavhengig prediktor både for klinisk tilbakefall og biokjemisk residiv.

\section{Anne Forus}

anneforus@hotmail.com

Tidsskriftet

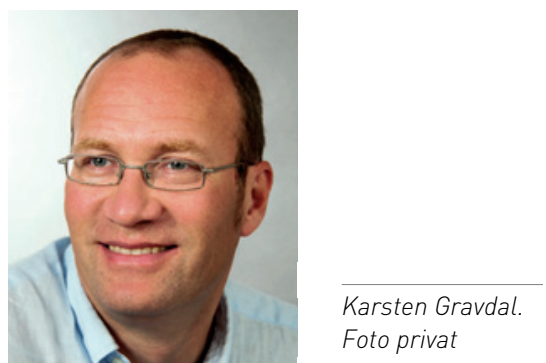

Disputas

Karsten Gravdal disputerte for ph.d.-graden ved Universitetet i Bergen 28.9. 2011. Tittelen på avhandlingen er Angiogenesis and epithelialmesenchymal transition in prostate cancer.

\section{Ordforklaring}

Biokjemisk residiv (biochemical failure): Tilbakefall av prostatakreft basert på måling av økt PSA-nivå 